
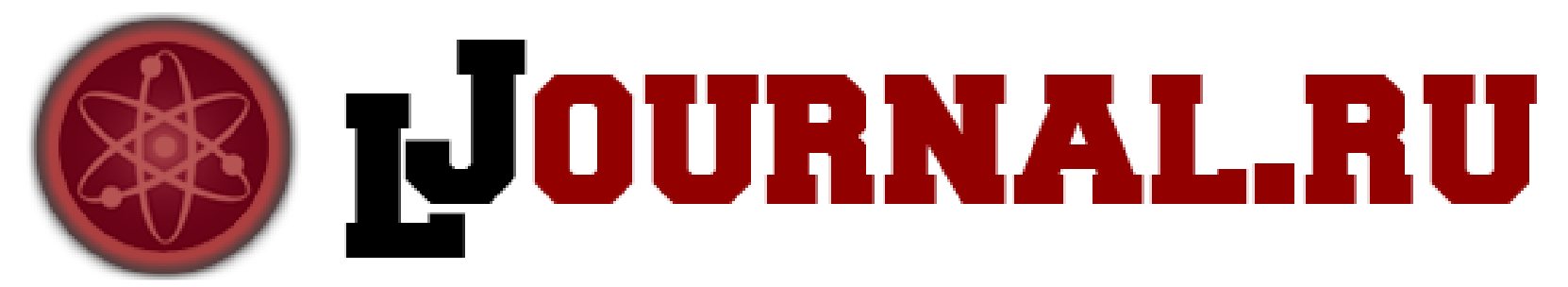

Якшанов П.А., Клишевич Н.Б.

Сибирский федеральный университет, Институт экономики, управления и природопользования Россия, Красноярск

doi: 10.18411/1j2016-2-32

\title{
Возможности разработки и внедрения системы эко-контроллинга в организации цементной промышленности
}

В качестве одной из стратегических целей государственной политики является необходимость соблюдения принципа устойчивого социо-экологоэкономического развития, что предусматривает усиление внимания к вопросам рационального природопользования и природоохранной деятельности на уровне субъектов хозяйствования. На практике это означает повышение заинтересованности предприятий в использовании средозащитных технологий, совершенствовании применяемых информационно-аналитических инструментов управления охраной окружающей среды с учетом требований международных стандартов.

Централизация роли экологического фактора в жизнедеятельности общества предполагает востребованность научных разработок, связанных с более детальной идентификацией природоохранных аспектов производственнохозяйственной деятельности, совершенствованием их анализа и оценки. Высокая стоимость технологий, позволяющих сохранять качественное состояние окружающей среды в условиях дефицита финансовых ресурсов у значительной части предприятий, предопределяет необходимость формирования программ стимулирования природоохранной деятельности цементного предприятия. 
Рациональное природопользование становится конкурентным преимуществом цивилизованного и социально ответственного бизнеса, что предполагает выявление и мобилизацию внутренних резервов и возможностей каждого хозяйствующего субъекта по достижению эффективности природоохранной деятельности на основе осмысления ее сущности, функций, факторов и ключевых направлений, а также решения других прикладных задач.

Возможности и преимущества контроллинга в цементной промышленности по сравнению с другими системами управления обусловлены взаимодействием подсистем контроллинга (методологией, процессом, структурой и техникой), которые в свою очередь характеризуются элементами, целями, задачами, коммуникаций, функциональными структурами, системой документооборота и т.д. Таким образом, при построении системы контроллинга возможно выделить целевые направления, по которым необходимо осуществлять контроль при внедрении его в деятельность.

Как любой бизнес-процесс операционного цикла, природоохранный процесс, несмотря на некоммерческий характер, должен содействовать достижению главной цели - поддержанию прибыльной деятельности и достаточного уровня рентабельности. Дополнительный положительный финансовый результат возможен, но отсрочен во времени.

Процесс природоохраны на цементном предприятии в большинстве случаев заключается в обеспечении возврата пыли, обращение такой пыли в производство.

На сегодняшний день объем невозврата неорганической пыли на российском цементном предприятии составляет порядка 1000 тн в год, т.е при себестоимости 1 тн клинкера порядка 1132,68 руб/тн; следовательно, затраты на технологические потери пыли составляют около 1 млн 132 тыс руб.

Предлагается плановый ежегодный экономический эффект от экологических мероприятий в части пылевозврата определять как произведение объема возвращенной пыли и себестоимости 1 тн клинкера.

Целесообразно применение критерия безубыточности для совершенствования управления природоохранной деятельностью цементного 
завода, реализуемое созданием подсистемы управления производством, в котором природоохранные мероприятия рассматриваются как самостоятельные бизнес-процессы. Управление ими тесно связано со стратегией предприятия и ориентировано на позитивное развитие взаимосвязанных элементов: ключевой процесс, ключевой ресурс, производство, затраты, создаваемая ценность.

В настоящий момент, предприятия российской цементной промышленности ориентированы на исполнение требований томов перечня сокращений предельно допустимых выбросов пыли, устанавливаемых Росприроднадзором. Однако, исходя из норм мировых стандартов, тенденций по экологизации предприятий и необходимости выхода на международные рынки сбыта продукции в условиях конкуренции актуально такое построение экоконтроллинга на предприятии, которое обеспечивало рост деловой репутации (гудвилла) и цены предприятия.

Система эко-контроллинга благодаря подсистемам методологии, процесса, структуры и техники, расширяет возможности перспективного планирования и эффективной природоохранной деятельности, выхода на новые рынки и ускоренной окупаемости природоохранной деятельности.

Таким образом, заинтересованность цементного предприятия повышается, когда конечный результат отвечает мотиву достижения и поддержания достаточных темпов роста прибыли, позволяющих равнозначно наращивать и производственный, и социально-экологический потенциал предприятия, а также увеличивать рыночную стоимость активов. 


\section{Литература:}

1. Анопченко, Т. Ю. Концепция эколого-экономического подхода к экономической ценности окружающей среды / Т. Ю. Анопченко, С. А. Кармазин // Наука и образование: Хозяйство и экономика, бјс предпринимательство; производство и управление. - 2014. - №9 (52). - С.2527.

2. Аристархова, М. К. Механизм системного обеспечения устойчивого развития инновационной деятельности промышленных предприятий / M. К. Аристархова, А. Н. Пономарева. // Проблемы анализа риска. - 2007. - № 3. С. 222-236.

3. Глаголев, С. Н. Факторы, влияющие на возможность адаптации промышленных предприятий к современным условиям / С.Н.Глаголев //Экономический анализ: теория и практика. - 2009. - № 25 (154). - С. 63-66. 